Queer(ing) Popular Culture: Homo-Erotic Provocations from Kinshasa

Thomas Hendriks

African Studies Centre, University of Oxford, Oxford, UK

African Studies Centre, 13 Bevington Road, Oxford OX2 6NB, UK

thomas.hendriks@africa.ox.ac.uk 


\title{
Queer(ing) Popular Culture: Homo-Erotic Provocations from Kinshasa
}

\author{
Contemporary African societies are regularly depicted as inherently homophobic cultural \\ spaces by Western media. Drawing on ethnographic fieldwork among self-consciously \\ effeminate fioto men and their so-called 'normal' boyfriends in Kinshasa (DRC), this article \\ troubles such monolithic images of 'African homophobia'. My interlocutors' deliberately \\ provocative readings of music, video clips, urban painting and street performances bring to the \\ fore surprisingly queer complicities within popular culture. Rather than dis-covering a 'gay' \\ subculture hiding in the shadows of the city, this article reveals the possibilities for sexual \\ eccentricity at the surface of urban life and demonstrates how, despite its often moralistic and \\ sometimes violent messages, popular culture is itself always already queer. Moreover, \\ pointing at the usually overlooked homoerotic affordances of urban ambiance as a social field \\ for the accumulation of 'transgressive capital', my fioto interlocutors celebrate the \\ proliferation of queer desires in spite of - and, perhaps, because of - everyday performances \\ of homophobia.
}

Keywords: homophobia; homosexuality; popular culture; youth; hedonism; music; transgression; Democratic Republic of Congo

Over the last two decades, a wave of homophobia seems to have taken hold of political discourses, public debates and moral imaginations in diverse African settings (Thoreson 2014). In Western media, Africa is regularly depicted as an inherently homophobic continent and thereby, explicitly or implicitly, opposed to a supposedly liberal West. 'Africa' and 'homophobia' are often firmly wedged together, producing the idea of a widespread and monolithic cultural refusal of homosexuality and calling for often well-meant international solidarity with African sexual minorities (Gunkel 2013). The idea of 'African homophobia' is primarily triggered by politicians, pastors and spokespersons of 'culture' and 'tradition' who claim that homosexuality is per definition un-African (Ndjio 2012). But, from the opposite side, the same idea implicitly returns in sexual and human rights discourses that remain strongly invested in the apparent truth of a homophobic African culture - an image that uncannily resembles the discursive (post)colonial construction of a 'heterosexual Africa' (Epprecht 2008). 
Recent critical scholarship has, however, convincingly argued that such contemporary homophobias do not express supposedly 'innate' African fears of homosexuality but are products of on-going changes in gender relations, societal shifts and particular national trajectories of political contestation, as well as partial and unintended results of international LGBT advocacy and its 'anti-Western' backlashes (Awondo et al. 2012). This article directly contributes to this scholarship by further opening up the unhelpful black box of 'African homophobia'. But instead of contextualizing and historicizing its political and moral production, I dwell on its often-overlooked failures. Rather than debunking monolithic 'African homophobia' by highlighting its important differences in diverse social and political settings, this article presents an ethnography of the cracks and fissures within specifically situated manifestations of popular homophobia itself.

Following the lead of the self-consciously effeminate or so-called fioto men in Kinshasa, with whom I conducted twelve months of ethnographic fieldwork between 2013 and 2016, this article argues that a one-dimensional focus on homophobia erases many of the complexities and ambiguities of queer life in urban DR Congo. While I certainly do not underestimate the obstacles many of these young men face - from pressures within the family, over deliberate neglect and hostility by health practitioners, to violence from police officers - an exclusive focus on injustice and discrimination obscures the otherwise surprisingly queer ambiance of Congolese cities.

A particularly salient vantage point from where to foreground the manifold possibilities for queer eccentricity in urban Congo is popular culture. Indeed, insofar as popular culture is an expression of popular 'consciousness' (Barber 1987), and insofar as this consciousness - as many seem to take for granted - is inherently homophobic, popular culture should express a supposedly shared popular homophobia. But while several manifestations of contemporary Congolese popular culture clearly express moralistic, hostile and sometimes even violent messages, fieldwork reveals much more complicated semiotic chains and ambivalent layers of meaning.

Together with my fioto interlocutors, I will therefore read music, video clips, urban painting and street performances to highlight how and why popular culture itself is always already queer. To do so, this article presents a selection of six deliberate provocations that fundamentally upset the assumed monolithic heteronormativity of popular culture, thereby 
recursively extending fioto politics and poetics into academic practices of knowledge production. My fioto interlocutors indeed take great pride in their skilfully mastered 'art of provocation' through which they claim to make men 'fall' (kokweyisa $\left.{ }^{l}\right)$ into their erotic world. This article deliberately repeats such provocative fioto gestures as a way of further queering African Studies (Ekine and Abbas 2013). Indeed, if popular culture itself is often already provocative (Bakhtin 1984), it is first and foremost by out-provoking its provocative stance that one can make its queerness manifest. And, as we will see, it is by deliberately provoking the city and its audiences that queer bodies reveal themselves in the very cracks and failures of official heterosexist ideology.

\section{Ambiance and the homoerotic economy}

While same-sex sexual acts have never been criminalized in the Democratic Republic of Congo, public attitudes towards the supposedly latest urban 'fashion' of homosexuality are often dismissive (Reid 2003). Overt displays of gender non-conformity and sexual dissidence are, for instance, regularly condemned in churches or on television programs. Nevertheless, many men are able to engage discreetly in same-sex erotic relationships, as long as these do not interfere with marriage obligations and procreation. Others, on the other hand, courageously defy the moralizing gaze of urban publics and openly express their gendered and erotic dissidence. Most, however, carefully navigate between situations where they can, as they say, 'relax' (kolembisa) and situations where they need to 'submerge' (L: kozinda), if they want to avoid being publically exposed in a wrong place or at a wrong time. Such alterations between relaxing and submerging not only rhythmically mark everyday queer life in Kinshasa, but also point at a distinction my interlocutors make between men and boys who are (usually) discreet and others who are (usually) open about their sexual habits and tastes.

Differentiating men according to their perceived 'respectability' also intersects with a second vernacular distinction that produces a tightly policed difference between gender-dissident fioto men and gender-conforming normal men (Hendriks 2016). While the first are thereby said to occupy a receptive position in sexual intercourse, the second would take on a penetrating role. The term 'fioto' then specifically denotes a self-consciously effeminate and dissident masculinity that manifests itself in many ways - one among which is a sexual desire

\footnotetext{
${ }^{1}$ Words in italic and between brackets are Lingala or French terms my interlocutors commonly use in everyday parlance.
} 
for 'normal' men. Although sometimes defied in practice, this vernacular fioto/normal distinction is a structural characteristic of the homoerotic economy in urban DR Congo. It resonates with a broader gender matrix that singles out receptive partners in same-sex relationships as sexually different -i.e. as homosexuel or pédé-without therefore automatically assuming a different sexuality for their 'normal' partners.

As suggested above, this fioto/normal differentiation intersects with that of respectability. Fioto men thereby see themselves as either réglos or folles, whereby the first usually 'hide' their effeminacy, while the second 'have no more reputation to lose' and are, therefore, able to be publicly visible. 'Normal' men, in turn, are differentiated between so-called papas who largely conform to the moral and social expectations of male adulthood and aventuriers who contest and transgress such gendered norms. This distinction resonates with the broader social and cultural significance of transgression in Congolese urban societies. It specifically points at the entanglement of the homoerotic economy with what kinois themselves call 'ambiance': a certain hedonism that emerged in the Belgian Congo around the activities of 'free women' (ndumba) and through which a city like Kinshasa came to define its own character or kinicité (Biaya 1996, Gondola 1999, Martin 1995, Hunt 2016:246-48).

This 'ambiance' can best be understood as the collective embodiment of a self-proclaimed national ideology of transgression or as a 'cultural intimacy' (Herzfeld 1997) that, depending on one's moral discourse and audience, is either the country's pride or shame. Ambiance thereby constitutes a specific social and symbolic 'field' (Bourdieu 1979) that rhythms everyday life in Congolese cities, in opposition to and in constant dialogue with other important fields, such as family, church and state, each with their own norms, possibilities and exclusions $^{2}$. In everyday life, ambiance is intimately linked to the paradigmatic urban space of the bar (nganda) and denotes a permissive atmosphere of music, dance and beer, where ambiançeurs of all kinds turn their transgressive behaviour into a badge of honour ${ }^{3}$. And, as we will see, it is primarily within the urban sphere of ambiance that folles and aventuriers play their games in erotic transgression for everyone to see and talk about. The

\footnotetext{
${ }^{2}$ The 'fields' of family, church and ambiance comprise what Katrien Pype (2012: 234) conceptualizes as the three dominant gender 'games' in Kinshasa: lineage-related codes of marriage, Christian morality and urban hedonistic modernity.

${ }^{3}$ Kinshasa is far from the only city where local inflections of 'hedonism' define urban modernities. See, for instance, Aterianus-Owanga (2016) for Libreville, Dorier-Appril et al. (1998) for Brazzaville, Newell (2012) for Abidjan or Ferguson (1999) for the Zambian Copperbelt.
} 
simultaneously celebrated and denounced sphere of ambiance is indeed crisscrossed with queer energies and possibilities that are skilfully tapped and rechanneled by fioto men - and, to a lesser extent, by their 'normal' lovers and partners.

The following provocations moreover show that the field of ambiance is intimately linked to popular culture, not just as a domain upon which musicians, painters and performers comment but also, more fundamentally, as a sphere of possibility that is produced by popular culture. Focussing on the nexus between urban ambiance and popular culture, the following provocations illustrate how and why queerness is not merely banned towards the shadows of the city but also emerges in its bright spotlights. They demonstrate how queer dynamics operate alongside and beyond family pressures, public opinions, religious discourses and state practices that would otherwise merely wish them away.

\section{Provocation 1}

One of the most iconic forms of Congolese popular culture is urban painting (Fabian 1996, Jewsiewicki 2003). Although popular paintings often provide a self-consciously critical narrative on history, politics and society, explicit depictions of same-sex erotic practices are extremely rare. There are, however, some exceptions. The famous Kinshasa-based artist Chéri Chérin, for instance, strikingly captures the political imaginary of popular homophobia in a tableau from 2008, which is aptly titled Les Nouveaux Maîtres du Monde ('The New Masters of the World') (fig. 1).

[Figure 1]

Fig. 1: Les Nouveaux Maîtres du Monde by Chéri Chérin (courtesy of the artist)

When I visited the artist in 2016 and asked him why he had decided to put two kissing men on this captivating painting, he first gently avoided the subject and referred me to two of his colleagues who, so he claimed, were better suited to talk about 'that world' (monde wana) of men who have sex with men, which appeared to exist all around him but about which he denied to have any direct knowledge. Moreover, he added, the meaning of these two kissing men is quite obvious: 'this is popular art, even a child can see what I want to say'. As often happened, Chéri Chérin refused to engage in any direct form of explanation or interpretation of his work, claiming to put in paint what everyone already understands. Les Nouveaux 
Maitres $d u$ Monde thus depicts a popular political cosmology, in which we see how today's planet is ruled by 'new masters', managing the world to their own benefit and to the exclusion of ordinary Congolese.

The painting for instance shows the G8 as an international organization posed on top of dark eyes representing the occult world from where it taps its powers, while ordinary citizens struggle to climb towards it in order to receive the gift of wealth coming from that hidden sphere of elite business and politics. On the right hand side, we see how the Internet provides the means through which our world is managed by these new masters, but also how it offers possibilities for organizing popular revolts and manifestations. But Chéri Chérin not only depicts a political cosmology; he also visualizes its underlying erotics of power. A white woman with naked breasts is ecstatically positioned in front of the eyes looking out from the occult world, as if they almost accuse us for looking at her. And two kissing men appear just next to the globe on which a woman tries to comfort an old man.

The prominent 'gay' kiss in this painting seems to refer to omnipresent popular discourses and conspiracy theories that immediately link same-sex erotic practices to power, money and the occult world. In this respect, it is of course no coincidence that one of the two men appears to be white while the other appears to be black. Such interracial intimacy is metonymic for the widespread understanding of so-called 'homosexuality' as a Western practice or deliberate ideology imposed on African societies. From such a perspective, homosexuality would not only be 'on the rise' because it is imposed by the new masters of the world but also because it is so eagerly imitated by Congolese looking for ways to connect to the outside. It is through such mimetic logics that same-sex practices are explained as the latest fashion in town, corrupting urban youth and undermining traditional African norms and values. In this painting, Chéri Chérin directly refers to this recent proliferation of discourses about 'homosexuality' in Congolese media. But rather than isolated instances of popular homophobia, these discourses belong to a larger set of moral and religious anxieties about the perceived state of the world.

From the perspective of a profoundly Pentecostalized urban imaginary, the apparent proliferation of same-sex practices is indeed often read as an eschatological symptom of the coming of the End Times (van Klinken 2013). Same-sex practices are thereby understood as occult techniques used to obtain power and wealth through illicit means. Male so-called pédés 
would then belong to secret satanic sects, practicing anal penetration in order to 'steal' or 'eat' the life force (or 'star') of other men, or to maintain the functionality of a specific medicine (nkisi) (Hendriks 2017). Hence, in popular imaginations, paradigmatic 'homosexuals' are not only effeminate men and boys in the neighbourhood but also powerful businessmen and politicians whose wealth and success is explained - and criticized - by way of a postcolonial occult economy of sodomy.

Les Nouveaux Maîtres du Monde thus depicts a vernacular critique on post- or neo-colonial exploitation, in which an interracial - and, from the black partner's perspective, somewhat reluctant - gay kiss comes to stand for the dynamics of power and desire that entangle the DRC in a global economic and political system. In a world where so many things happen because of the secret manipulations of the elite in occult spheres of action from which ordinary Congolese are excluded, the search for connection, for new wealth medicine, and for secret knowledge becomes a structuring drive in everyday life. In this painting, Chéri Chérin not only visualizes what Jean-François Bayart calls the 'baroque relationship between Africa and the rest of the world' (2000: 252) but also criticizes and ridicules the strategies of 'extraversion' that political elites use to mobilize resources (ibid: 222). Such logics of extraversion indeed underlie the vernacular political cosmology Chéri Chérin depicts, in which power and wealth always originate from the outside and have to be captured and appropriated through contact with that outside - although, as the depicted kiss suggests, sometimes through reluctant submission.

While Chérin presents himself as merely a transmitter of vernacular worlds and histories, he also considers himself a moral educator - he preaches in a nearby church - who, through his paintings, urges people to think and, ultimately, change the world. In Les Nouveaux Maîtres $d u$ Monde, he deliberately uses homosexuality as a way to capture people's attention, thereby reconfirming the popular imaginaries according to which same-sex practices and desires are understood as occult strategies of extraversion. The painting's moral message is thus diametrically opposed to what many LGBT activists in today's Kinshasa fight for: for many of them, Chéri Chérin only depicts the 'backward' views and superstitions of a noisy majority.

However, as some of my fioto interlocutors remarked, Les Nouveaux Maîtres du Monde is not so much directed against same-sex desire as such, but rather against a particular interracial 
homoerotic economy in which what is most shocking is not the queer kiss but the structures of dependency and inequality it both hides and uncovers. At the same time, Chérin's explicit depiction of queer desire opens up discursive space for public discussions about same-sex intimacies that are never predictable in their outcome. While the painting clearly reproduces popular stereotypes, it is itself part and parcel of the queer visibility it seems to denounce.

Chéri Chérin's refusal to directly talk about 'that world' indeed indirectly reveals his astute knowledge of what is actually going on. When he referred me to two of his colleagues famous kinois artists in their own right - he indeed obliquely admitted to be 'in the know'. His two colleagues, in turn, referred me to others and, in the end, everyone seemed to know 'this world' as much as anything else. Hence, rather than attributing a generic homophobia to popular culture, this first provocation suggests that one might also follow its unpredictably queer trails. And, as fioto men in Kinshasa often point out, there is always so much more than meets the eye. What might initially look like homophobia, they suggest, always contains a queer underneath that needs be seduced into existence through their always-risky games of provocation.

\section{Provocation 2}

One of these unpredictably queer trails leads to media and, more specifically, to 'popular journalism' and the multitude of discussion forums, interview formats and call-in shows that have emerged in the DRC since the liberalization and commercialization of its media landscape in the 1990s (Pype 2012). Among the topics and issues that are eagerly discussed on television, sodomy, so-called 'lesbianism' and pédéisme have become quite popular over the last decade.

At first sight, the depiction of gender and sexual dissidence on television seems extremely negative, producing sensational and stereotypical images that satisfy viewers' curiosity, as well as providing yet another confirmation that today's world is really near its apocalyptic end. One of the most notorious outlets for popular journalism is, for instance, a programme on the private television chain MolièreTV, called KinMakambo ('Kinshasa's Problems'). It offers a format for ordinary kinois to provide footage of particular events in their neighbourhood to MolièreTV reporters, who then come to interview people about what has happened, probing their reactions and opinions (Pype 2011: 121-123). As its name indicates, this programme 
frequently focuses on everyday problems - such as electricity cuts, flooding, and interruptions in water supply - but also screens images of assumed thieves, criminals and rapists who have been captured by 'the people' and are interrogated, and sometimes abused, in performances of popular justice.

It is in this category of assumed moral offenders that supposedly 'homosexual' men sometimes appear on KinMakambo, often after they have been caught red-handed. These men, quickly attracting a crowd of people, are often kept in a small room or tied to a tree while bystanders make sure that their shamed faces are recognizably captured on camera. MolièreTV reporters then usually interview agitated onlookers who invariably voice their moral indignation about the purported act of abomination. When they appear on television, such images are intensively discussed and, later on, sometimes reproduced on YouTube, Facebook and Internet forums through which they are shared and circulate widely through the city ${ }^{4}$.

The sheer violence and aggression contained in such painful images of popular justice against perceived sexual dissidents seems to confirm once more the harsh 'homophobia' of public opinion in the DRC. For fioto men and boys, these images indeed serve as warnings about what might, one day, happen to them. Whenever yet another story from KinMakambo hits the city, they viscerally feel the violence and react with horror to its images, some of which are downloaded and shared on mobile phones as permanent reminders of a common vulnerability and as a visual record that enables the formation of queer affective communities and counterpublics. Moreover, despite all the violence and aggression, and despite the apparently insurmountable moral law against which they are found guilty, programmes such as KinMakambo also offer spaces for dissident voices to actively contest public opinion and unveil its hypocrisy.

MolièreTV reporters are indeed known to sometimes give the floor to the accused themselves, who can thereupon take the audience by surprise when, instead of refuting the claims made against them or 'confessing' their sins, they proudly identify as pédé and reaffirm their presence in the city. Whenever they thus 'talk back' on television, captured fioto men have the opportunity to deflect moral accusations and redirect them to the public in general. In one

\footnotetext{
${ }^{4}$ E.g. https://www.youtube.com/watch?v=LFiBvrwxuyY (Ba maman kangi ba pede ba zo sala action na zamba; 'Women caught homosexuals who were doing it in the bushes')
} 
such instance, a well-spoken and self-assured fashionable young man provoked the reporter by saying that 'the man over there is indeed my husband and we had sex, like all husbands and wives do. But I also had this man, and that man, and that man's brother, and so many others in this neighbourhood', pointing at individuals in the assembled crowd. By thus talking back, fioto men reintegrate themselves in an erotic network that transcends the specific act under consideration and implicate a large number of 'normal' men as complicit to the act they now so loudly condemn. Hence, while KinMakambo certainly transmits horrid stories and images, in which assumed homosexuals are victims of mob justice, MolièreTV also gives a surprising voice to sexual dissidents, some of whom take the opportunity to play the game of provocation and reveal the complicity of those who pretend to hold the moral high ground through the same format.

\section{Provocation 3}

The often-shocking videos produced by this kind of popular journalism are, however, merely one strand in a quickly growing tapestry of images that deal with the issue of sexual dissidence in Congolese media. While the footage from KinMakambo is often quite violent and only allows for queer voices in the margin, several Congolese news sites like Avis $d u$ Public or CongoMikili, produce reports, interviews and documentaries on the issue that allow for more nuanced views. Within the digital space offered by these media who often target Kinshasa's youth, the question of so-called 'homosexuality' is seriously explored, informing a wide range of opinions, reactions and (queer) agencies ${ }^{5}$.

These programmes generally consist of interviews in which self-identified and usually quite visible fioto men are given a platform for expressing themselves and addressing a larger urban public. Often, such interviews provide ample opportunities for deliberately provoking their audience by explicitly stating usually unspoken truths. It is, for instance, not uncommon for these interviews to turn into explorations of technical sexual matters, with interviewers asking about the possibilities, particularities and pleasures of anal sex - and comparing them to vaginal intercourse. While such sensational topics might be deliberately brought up in order to appeal to popular fascinations, interviewees frequently manage to establish seducing and

\footnotetext{
${ }^{5}$ For other examples of the making of queer spaces in African (online) media, see for instance Mwangi (2014) or Tsika (2014).
} 
joking relationships with their interviewers ${ }^{6}$. Although the latter therefore sometimes feel the need to distance themselves from what has been said - usually in a moral summary provided after the interview itself - they simultaneously establish a connection with their interviewees through which queer energies and fluxes appear on screen and playfully connect to a broader urban audience.

While such fioto appearances on Internet news sites, discussion forums and Facebook pages clearly contribute to the reproduction of certain stereotypes, they simultaneously transmit a widespread fascination with erotic transgression that operates alongside expressions of popular homophobia. My interlocutors themselves often claim that the regular appearance of trendy fioto youth on local media helps to create what one might perhaps call a nascent 'fioto craze' in kinois nightlife ${ }^{7}$. As the following examples in this article further illustrate, the mainstream bar scene in Kinshasa is indeed increasingly marked by the colloquial figure of the fioto (or mades) as one of its contemporary protagonists, who help to define and reproduce urban ambiance itself (alongside the well-known figure of the ndumba or 'free woman'). Moreover, within the field of urban nightlife and its generalized economy of transgression, some fioto men have managed to establish a certain celebrity status by accumulating provocative capital through public performances of sexual and gender transgression.

One of the best-known public fioto figures in contemporary Kinshasa is Patrick Lokwa (also known as Sekayi Mama), who established his name and fame through explicit interviews given to reporters from news providers such as La voix du peuple ${ }^{8}$. When in January 2016 the popular female gospel singer Marie Misamu unexpectedly passed away in Kinshasa, Patrick Lokwa became one of the most visible figures claiming Misamu's heritage and confirming her status as a queer heroine. Moreover, a recent reportage from Infomondiale reveals Patrick's popularity in his own neighbourhood, where people not only 'accept' his presence but actively celebrate his friendliness, beauty and elegance, refuting any negative suggestions

\footnotetext{
${ }^{6}$ E.g. www.youtube.com/watch?v=Mk2tfOX59fM (Ba homosexual ba bimisi ba vérités choquantes, pedai moko a drague journaliste en plein interview; 'Homosexuals say shocking things, one pédé seduces a journalist during the interview').

${ }^{7}$ I use the term 'fioto craze' to point out the striking analogies with the so-called 'pansy craze' described by George Chauncey (1994) for 1930s New York.

${ }^{8}$ E.g. interviews in which Patrick is confronted to a female counterpart who challenges his femininity: www.youtube.com/watch?v=pdJ91r61KU4 (+20 ans: Pede Patrick ba seduite pe ba embrasse ye epa tendresse en plein emission, azongi mobali!; ' +20 years: Pédé Patrick is seduced and kissed at tendresse in full broadvasting, he became a man [again]').
} 
made by the reporter ${ }^{9}$. Although sexually provocative and playfully boastful about his 'capacity of being pédé' (kipede), Patrick Lokwa claims a certain respectability and even manages to re-inscribe his queer voice into the field of religion, where gender and sexual norms are otherwise strictly enforced.

My interlocutors often use the example of Patrick Lokwa for demonstrating how fioto men can and do flourish, despite the difficulties they encounter. As a publicly celebrated queer figure, Patrick indeed captures social and cultural dynamics that reveal a much more welcoming attitude to difference than what blanket attributions of 'African homophobia' might suggest. Although often overlooked, this everyday openness to singularity and multiplicity in contemporary Kinshasa seems, however, nothing new. It could, for instance, be understood as an iteration of what Jane Guyer (1996) calls Central African 'traditions of invention'. By inverting Hobsbawm and Ranger's (1983) invention of tradition and reanchoring invention in tradition, Guyer has indeed shown how these traditions were often very much focussed on the 'social production of multiplicity' through the deployment of 'centrifugal forces of novelty, performative skill and invention' (1996:2).

In a similar way, contemporary Kinshasa seems to provide a social space where 'human variation [is] treated as a valued potential asset to be created and assiduously cultivated' and where 'idiosyncrasy [is] explained as "he's just like that"” (ibid: 10). Filip De Boeck indeed notes that although this urban world 'imposes a strong and dominant necessity to conform [...] this conformity is always double-edged and continually unravels in a disorderly, often playful but sometimes also violent plurality’ (De Boeck and Baloji 2016: 125). Hence, notwithstanding the strong pressures to conform that usually capture the attention of LGBT activists in the city, Kinshasa is also full of possibilities for cultivating individual singularities and queer eccentricities - despite and through the very violence they generate.

To a certain extent, preferring men or women, or walking with an extravagant feminine swing or rather with a cool masculine pace are thus idiosyncratic individual tastes, preferences, habits and qualities, which together with one's personal skills and past experiences define one's 'way of being' (ezaleli, façon d'être): a holistic notion of personal behaviour, individual

\footnotetext{
${ }^{9}$ E.g. www.youtube.com/watch?v=1JFv6NV6IbY (Famille ya Patrick Lokwa babimisi vérité pona nini a koma pede bolanda histoure ya bie naye; 'Patrick Lokwa's family tell the truth about why he became a pédé, hear the story of his life')
} 
character and stylistic mannerisms through which kinois carefully craft their persona in different social settings. In general, gender transgressions and reversals are often accepted as simply the way things are, without therefore automatically signalling non-heterosexual desires ${ }^{10}$. At the same time, however, the pragmatic tolerance for individual idiosyncrasies also always entertains at least the possibility for erotic dissidence and even, as the following provocations further highlight, for an open celebration of queer eccentricity and stylistic invention.

\section{Provocation 4}

The widespread but ambivalent fascination for the fioto figure is reflected in a growing set of performative characters and fioto impersonations in contemporary Congolese popular culture. While fioto characters seem to be uncommon in the nascent field of Congolese film production - in comparison to the much larger field of Nollywood films, where 'homosexuality' has become a sensationalized topic and given rise to its own popular (sub)genres (Green-Simms 2012, Green-Simms and Azuah 2012), Congolese television series increasingly stage pédé or lesbian characters (Pype 2012: 270). However, just as in most Nollywood films, these (Pentecostal) TV dramas depict and morally condemn homosexuality as associated with greed, criminality, incest, prostitution and occult powers, having their pédé characters running into serious trouble, if not their own death.

Fioto characters are also becoming increasingly popular in contemporary Congolese theatre, and especially in comedy. Whereas cross-dressing has never been uncommon in Congolese theatre and does not automatically suggest gender non-conformity or non-heterosexuality on the part of cross-dressing actors ${ }^{11}$, fioto impersonations often do give rise to such rumours, creating a sphere of mystique in which careers can be made. Mike La Duchesse, for instance, the first well-known actor who made his name by playing a pédé character, often actively maintains some confusion between on-stage and off-stage performances of effeminacy

\footnotetext{
${ }^{10}$ The notion of mwasi mobali, for instance, refers to women who make a professional career and often manifest themselves as 'powerful' and 'masculine' on the urban stage.

${ }^{11}$ See, for instance, the popular comedian Freddy Bonganda, whose well-known character 'Maman Mbaliosombo' does not raise any questions about Bonganda's masculinity or 'normal' sexuality.
} 
(lisamboli), thereby deliberately generating gossip, suspicion and doubt about his 'true' sexual identity or erotic preferences ${ }^{12}$.

Although such performances of kipede in Congolese TV series and theatre are invariably stereotypical and sometimes even derogatory - and, in the case of comedies, actually produce their comic effects through stereotyping and ridiculing - they are not necessarily perceived as embarrassing by fioto men and boys themselves. While the emphasis on witchcraft and the occult in TV series is often disturbing to fioto viewers, most of them find the pédé characters in popular comedy quite funny. Laughing about the same jokes and sketches as everyone else, and downloading video clips by theatre companies and comedians on their smartphones and sharing them with others, they thereby actively confirm their partial belonging to a wider urban public.

Another comic personage who is becoming increasingly visible in Kinshasa's public space is the ambulant vendor who dresses up as a woman in order to sell cosmetics on the streets. Such vendors are usually young men in their twenties who make a living by selling beauty products and female clothing to women, carrying their merchandise on their heads (like women) and dressing in tight skirts and blouses that accentuate their fake buttocks and breasts ${ }^{13}$. As hybrid figures between the bana verni (literally 'polish children' or young boys who sell and apply nail polish to customers) and the so-called kalayi ngangu or street comedians (Pype 2015a), these cross-dressing street vendors are often enthusiastically received on terraces, bars and market stalls where people come together. They invariably walk in an exaggerated way, swinging their obtrusive buttocks, flirting with male bystanders, gossiping with female customers and sometimes pretending to be ndumba or 'free women'. Although they are occasionally pointed at as pédés, most of them maintain that they are simply performers. Describing their daily activities as 'work' (mosala) or even as 'art', they

\footnotetext{
${ }^{12}$ E.g. https://www.youtube.com/watch?v=QwHvMmIGoVQ (Bolanda comedie ya Duchesse, Pululu, Micho na tournage ya kader; 'Follow the comedy of Duchesse, Pululu, Micho during the making of kader').

${ }^{13}$ E.g. https://www.youtube.com/watch?v=xq7j3iOSxDo (Pédé ou Kalayi Ngangu: A Kinshasa les garcons se déguisent en filles pour moyen de vivre; 'Pédé or street comedian: In Kinshasa boys dress as girls to survive').
} 
define themselves as courageous young men or Yankees $^{14}$ who take care of their families and do what needs to be done to earn some money.

Once again, such street performances are very stereotypical and can thus be seen as expressions of an assumed popular homophobia. But, in fact, figures such as these are often quite ambivalent. It is, for instance, not uncommon for such cross-dressing ambulant vendors to jokingly compete and interact with groups of publicly visible fioto men (or folles) who happen to cross their way. These interactions between men who merely perform a gendered sexual dissidence and individuals who 'are' gender or sexually dissident trouble the very distinction between performance and being. Indeed, if fioto men are often said to 'act' like women, cross-dressing comedians and street vendors act like they act like women. To a certain extent, acting like one is acting can undermine one's acting in the first place and thus raise doubts that one is actually expressing an inner truth and, thus, not acting at all (Newton 1972). So, while stereotypical performances can of course lead to ridiculing, stigmatizing and excluding sexual 'others', they also contribute to a certain colloquial normalization of erotic idiosyncrasies and queer eccentricities.

\section{Provocation 5}

The Congolese music scene is yet another important domain of popular culture in Kinshasa. In the following example, I will therefore further illustrate the queer possibilities of the vernacular notion of 'ambiance' by reading, with my fioto interlocutors, a recent song that takes ambiance as its own subject matter.

In 2015, Kinshasa was dancing on the latest hit by the popular musician Ferre Gola, whose new song, Seben, directly pointed at the city's famous ambiance and introduced a new choreographed dance (called facilité), which spread like wildfire through the city. Originally the name for the characteristic guitar solo in rumba music, Seben came to indicate the fastpaced dance sequence that, in most Congolese music, typically follows on a slower and more lyrical first section (White 2008: 52-58). Today, Seben is often identified with the so-called générique: the rhythmic opening track on each album, in which the atalaku or animator

\footnotetext{
${ }^{14}$ Originating in the youth subculture of the 'Bills', who modelled their transgressive masculinities on the iconic figure of the Hollywood cowboy in 1950s and 60s Léopoldville, 'Yankee' has become a widely used term for self-identified 'tough' young men who know how to navigate the dangers and opportunities of the urban world (Gondola 2016).
} 
encourages people to dance with ecstatic shouts (ibid). While Ferre Gola's Seben became an immediate hit in Kinshasa's bars and night clubs, few would have guessed that, in the world of fioto men and their 'normal' boyfriends, it would be taken as a queer sign.

Many of my interlocutors indeed proudly stated that the accompanying video clip clearly demonstrated, as they said, the superior dancing and ambiance skills of 'people like us' ${ }^{15}$. They thereby identified a group of young men in the video clip as fioto. Although it might take a trained eye to notice, the young men's clothing, hairdos and dancing style seemed to betray a certain effeminacy that was regularly remarked upon, not only by fioto men and boys themselves but also by people 'in the know' who had the capacity to see beyond the surface of things. But, what is even more, for urban ambiançeurs and other self-proclaimed experts on Congolese nightlife, the presence of these apparently slightly dissident dancers in a Ferre Gola video clip was not surprising at all and taken as a sign of good ambiance itself.

Like in most Congolese video clips, single-sex groups of men and women alternate on screen performing largely similar ndombolo choreographies. Although readings vary, ndombolo dancing, with its suggestive hip rotations, is often seen as the paradigmatic expression of ambiance and therefore frequently demonized as hedonistic or satanic by pastors and elders in contemporary Kinshasa. Seben, however, also explicitly stages a third group of dancers: seven somewhat younger men who, as the video proceeds, increasingly exhibit a certain gender dissident 'folly', easily recognised by fioto men as lisamboli. Their exuberant dancing style and their separate position in between the other men and women indeed unsettle the strict gender binary that generally frames and produces erotic frisson in Congolese video clips.

Picking up and amplifying these non-heterosexual possibilities, fioto listeners quickly adopted the song as a secret ode to their seductive powers. This queer act of appropriation was very significant, they insisted, because of Ferre Gola's track record of open attacks on homosexuality. Only two years earlier, for instance, Ferre's previous album, Boite Noire, was strongly rejected by many of my interlocutors, because, in its générique, Ferre's atalaku Bercy Mwana had insulted Fally Ipupa, another big star of Congolese popular music (and idol of so many fioto men and boys). Bercy indeed deliberately shouted: Mobali mobimba

\footnotetext{
${ }^{15}$ https://www.youtube.com/watch?v=wByg4omA5jk (Ferre Gola - Seben - Clip Officiel)
} 
akomaka VW, alataka colan na kati string (literally: 'The real man is becoming a VW, he is wearing panties and a string'), thereby accusing Fally of being pédé by using the code name 'VW', which stands for Volkswagen and refers to the fact that, in the kinois imagination, Volkswagens (usually old VW kombis) have an engine at the rear end of the car.

Accusing Fally of wearing panties and strings and being driven by his 'rear-engine', Bercy Mwana, however, merely spelled out what everyone already knew. As the pretty boy of Kinshasa's music scene, Fally Ipupa became hugely popular over the last decade by mixing ndombolo, rumba, R\&B and American-style pop music. But his name has always been surrounded by rumours about his sexual tastes and preferences (and, specifically, about the relationship with his manager, David Monsoh). Like in other music industries (e.g. AterianusOwanga 2016 on Gabonese rap), such rumours about the dissident desires of its celebrities are nothing special and certainly nothing new in the world of Congolese music. Fally, it is often assumed, was 'initiated' into same-sex erotic practices by his former mentor Koffi Olomide, when he used to play in the latter's band Quartier Latin International. And, Koffi, in turn, is said to have been 'initiated' long ago by the late Papa Wemba in his band Viva la Musica.

There thus seems to exist a whole genealogy - and several lesser genealogies like it - that explain the reproduction of homoerotic habits and desires in Congolese music. In the popular imagination, the world of music is indeed intimately linked to the world of men who have sex with men. On the one hand, it is often assumed that managers and producers force upcoming musicians to have sex with them in return for financial and logistical support (a phenomenon known as 'faire le showbiz'). And, on the other hand, same-sex sexual practices are explicitly seen as occult techniques widely used by artists to guarantee their access to, and success in, the harsh Congolese music industry. In this sense, 'homosexuality' among Congolese artists and musicians is nothing but another symptom of their entanglement in the occult cosmology so vividly visualized in Chéri Chérin's Les Nouveaux Maîtres du Monde.

While, once again, such explanations for musicians' apparent erotic dissidence obviously express a certain homophobia, the same rumours also confirm and reinforce the queer possibilities that arise at the very heart of popular music itself. While these queer dynamics are often partially coded and only recognizable as such by those accustomed to or 'initiated' in 'this world' (monde oyo), respected musicians actively entertain homoerotic possibilities in their video clips, lyrics and public performances, sometimes even deliberately nourishing 
speculations about their erotic tastes. Moreover, while Seben hides in plain view what is so delightfully queer to those who 'know how to look', the following and last example plainly shows how open same-sex seduction also operates in the bright spotlight of ambiance, for everyone to see.

\section{Provocation 6}

Many of my fioto interlocutors in their late 30s and early 40s often referred to Papa Wemba's song Pénitence na ngai ('My penitence'), from his 2005 Bazonkion album, as a key moment in the popularization of same-sex erotics as part and parcel of Congolese ambiance. Its accompanying video clip indeed strikingly depicts the otherwise often covert queer possibilities of the interplay between hegemonic masculinity and sexual transgression.

The clip shows Papa Wemba on one of his travels to Europe, waiting for his girlfriend in a hotel room before going to a party ${ }^{16}$. As the girl is late, Papa Wemba decides to leave on his own and drives a Volkswagen beetle to a private nightclub called Le Night, where he picks up Guélord VIP, a well-known folle from Kinshasa. Back at the hotel, they enter a room filled with partying men and women, dancing and drinking to Papa Wemba's undulating voice. The fashionable Guélord, dressed in black leather pants and a tightly fitting top, and wearing conspicuous jewellery and sunglasses, initially dances among the many girls present, moving his fingers alternatingly up and down in the air - a dancing style known to many kinois as 'European'. Near the end of the clip, however, Guélord's dancing becomes more suggestive and he sensually throws his braided and extended hair backwards, in a gesture of selfconscious fioto effeminacy. In the final scene, we see him explicitly flirting on a sofa with Papa Wemba and reacting jealously to an approaching girl who angrily throws a glass of Champaign at Guélord's head.

While the song's main plotline is, of course, a failed heterosexual love story that pushes Papa Wemba to plunge into ambiance with a well-known fioto man in Paris, these very cracks and failures of heteronormativity open up possibilities for the expression of queer desire. And while the Champaign thrown at Guélord's head somehow symbolizes the punishment of transgression, it also expresses the jealousy and competition between women and fioto in their

\footnotetext{
${ }^{16}$ https://www.youtube.com/watch?v=XktzHbVWAj0 (Papa Wemba: Penitence na ngai)
} 
quest for men like Papa Wemba. Moreover, while the song is called Pénitence na ngai, which means 'My penitence' and thus points at the wrongs Papa Wemba committed instead of waiting for his girl, he also explicitly honours Guélord VIP with the epithet la beauté fatale in his dedications (mabanga) at the end of the song.

According to my interlocutors, Pénitence na ngai provoked a rapid proliferation of the idea that, in order to be a true star (a padre, maître or grand-maître) in music, nightlife and ambiance, a man should not just have a series of girlfriends but also, at least, several men and boys to publically show off as admirers. Rather than undermining one's masculinity, dating well-connected (branché) fashionable fioto guys, alongside sexy girls, indeed seems to make rather than break one's status as a celebrity. This idea strongly resonates with the broader social and historical significance of transgression in contemporary Kinshasa, where dominant masculinities are often made through the performance and celebration of transgression on the public stage (Gondola 2016).

Moreover, having girls and fioto men literally fight over one's attention not only reconfirms one's popularity and masculinity, but also resonates with the cult of fashion and style for which Papa Wemba was so well known. As one of the protagonists of the 1980s Congolese subcultural movement of the SAPE (Société des Ambiançeurs et Personnes Elégantes), Papa Wemba was indeed an exemplary sapeur who helped defining this ideology or 'religion' of dressing well. The video clip thus brings to the fore an often-ignored homoerotic aspect of the usually homosocial phenomenon of SAPE (Gandoulou 1989, Gondola 1999). And it is no coincidence that, in Ferre Gola's clip Seben, sapeurs and fioto dancers appear side by side as iconic figures of Congolese ambiance. Together, they reveal a popular fascination for transgression through which fame, reputation and masculinity is made.

\section{Popular culture is always already queer}

The preceding examples illustrate how performances of erotic transgression and fashionable cosmopolitanism come together in spaces of urban ambiance and its mediated representations. The current fashionability of same-sex erotic practices in the DRC and the queer affordances of its popular culture need to be understood in the context of a longue durée of extraversion and 'traditions of invention' that push popular imaginaries and fantasies to imagined otherwheres and material objects of otherness that are appropriated in gendered performances 
of connectivity. But contemporary queer performances and identities also seem to grow from a cultural history where cross-dressing and sexual reversals might have been far from uncommon in ritual contexts (e.g. Devisch 1985). While one cannot postulate any simple relationship between ritualized erotic transgressions and current fioto performances especially because these histories have largely been forgotten in contemporary Kinshasa today's ambivalent fashionability of same-sex erotics needs to be situated in a broader cultural genealogy of a 'visceral and enduring fascination' with transgression in the city (Gondola 2016: 201).

My emphasis on the pragmatic acceptance and even public celebration of queer eccentricities does not, however, intend to ignore the many difficulties fioto men and boys encounter in Congolese cities. On the contrary, it intends to demonstrate that, despite these obstacles, fioto men and their 'normal' boyfriends have significant opportunities to produce and accumulate transgressive capital, through which they can build a reputation in the culturally salient field of ambiance. This transgressive space of ambiance - simultaneously celebrated and denounced by the urban public - indeed resonates with an alternative erotic economy that, to a certain extent, bypasses the social and moral demands of kinship, marriage and family life. It thereby becomes a liminal laboratory for exploring other ways of living desire that participate in a broader attack on responsibility and gerontocracy in Congolese cities, whereby youth seem to replay older rhythms of transgression in a different guise (De Boeck and Baloji 2016, 185-188).

This article shows how the field of ambiance produces, and is produced by, a popular culture whose inherently transgressive dynamics allow for the proliferation of queer desires in spite of its 'homophobic' expressions. The six provocations indeed stage the publicly visible gender-dissident fioto or folle as a popular figure in urban imaginations and cultural practices. Notwithstanding its role in the reproduction of often-harmful stereotypes and its participation in spectacles of gendered violence, Congolese popular culture contains 'moments of freedom' (Fabian 1998) through which my interlocutors claim a queer presence in the city. As experts in provocation, fioto men are able to outmanoeuvre the provocative dynamics of popular culture itself, to beat transgressive masculinities in their own game, to manifest themselves at the very heart of urban ambiance, and to participate in a long history of extraversion, invention and reversal that allows for its own queer idiosyncrasies. 
In her seminal essay on popular culture in Africa, Karin Barber defined popular arts by their 'active exploitation of their unofficial status' $(1987,12)$ and the ways in which they 'rejoice in their freedom from the constraints of the official systems of conventions' (35). My fioto interlocutors taught me that, exactly because of this inherent unconventionality, popular culture itself is perhaps always already queer. From a fioto perspective, queering - or queer reading - is thus not so much the creation of a subcultural resistance as well as the maintenance of a complicity (Hall 1981) that does not separate a queer self from a supposedly 'normal' other but that reveals the queerness of the norm itself. Thereby unsettling the queer/normative dyad, fioto presence in Kinshasa relies on the arts of seduction and provocation that trigger and stimulate the queerness of the city and reconfirm fioto men and boys not as social outsiders but as insiders to an urban world complicit with the many transgressions it so loudly condemns. While similar queer practices and readings can be found in other African urban settings, Kinshasa and its self-conscious cultivation of ambiance make for a particularly lush proliferation of queer possibilities.

Although I believe that the inherent queerness of kinois popular culture and urban ambiance can ultimately be a source of inspiration and hope on a less violent world, it does not always sit comfortably with emergent LGBT and sexual rights activism in the city. For some of my activist friends, the above provocations merely point at the ephemeral nature of unofficial queer pleasures. Foregrounding queer possibilities in nightlife, music, theatre and popular art does not soften the irrefutable pain of queer desires being denied official recognition by family, church or state. I take their perspective very seriously. But after work, and when they are tired from struggling to make their sexuality respectable, many activists too indulge in the queer possibilities offered by popular culture and its fascination for transgression, dancing on urban rhythms that, as Karin Barber writes, 'have the capacity to pick up subterranean currents of thought that society itself may be unaware of' (4). The remaining question is, then: if popular culture itself is always already queer, what new possibilities and futures are generated through this (over)production of transgressive capital? And what does this mean for queer activism and queer theory in a contemporary world where the so-called South is so easily identified with homophobia?

\section{Acknowledgements}

This work was supported by postdoctoral research grants from the Bijzonder 
Onderzoeksfonds (University of Leuven) (2013-14) and Research Foundation-Flanders (FWO) (2014-17). I thank Carli Coetzee, Sudeep Dasgupta, Kristien Geenen, Peter Geschiere, Katrien Pype, Rachel Spronk and Jonny Steinberg for their insightful comments and suggestions. And I will always remain indebted to my fioto interlocutors for their provocative thinking, warm friendship, and wicked humour, although - for reasons of anonymity - this article is unable to give them the individual recognition they deserve.

\section{References}

Aterianus-Owanga, Alice. 2016. “'Libreville by Night': Célébrité, Sexualité, et Violence des Rapports de Genre dans le Monde de la Nuit."In La Violence de la Vie Quotidienne à Libreville, edited by Alice Aterianus-Owanga, Maixan Mebiame-Zomo and Jospeh Tonda, 69-91. Louvain-la-neuve: Académia Bruylant.

Awondo, Patrick, Peter Geschiere, and Graeme Reid. 2012. "Homophobic Africa? Toward a More Nuanced View." African Studies Review 55 (3): 145-168.

Bakhtin, Mikhail. 1984. Rabelais and His World. Bloomington: Indiana University Press. Barber, Karin. 1987. "Popular Arts in Africa.” African Studies Review 30 (3): 1-78. Bayart, François. 2000. "Africa in the World: A History of Extraversion.” African Affairs 395: 217-267.

Biaya, T.K. 1996. "La Culture Urbaine dans les Arts Populaires d'Afrique: Analyse de l'Ambiance Zairoise." Canadian Journal of African Studies 30 (3): 345-70.

Bourdieu, Pierre. 1979. La Distinction: Critique Sociale du Jugement. Paris: Minuit.

Chauncey, George. 1994. Gay New York: Gender, Urban Culture, and the Making of the Gay Male World, 1890-1940. New York: Basic Books.

De Boeck, Filip and Sammy Baloji. 2016. Suturing the City: Living Together in Congo's Urban World. London: Autograph ABP.

Devisch, Renaat. 1985. Polluting and Healing among the Northern Yaka of Zaire. Social Science and Medicine, 21(6): 693-700.

Dorier-Apprill, Elisabth, Abel Kouvouama and Christophe Apprill. 1998. Vivre à Brazzaville: Modernité et Crise au Quotidien. Paris: Karthala.

Ekine, Sokari and Hakima Abbas. 2013. Queer African Reader. Nairobi: Pambazuka Press.

Epprecht, Marc. 2008. Heterosexual Africa? The History of an Idea from the Age of Exploration to the Age of AIDS. Athens: Ohio University Press.

Fabian, Johannes. 1996. Remembering the Present: Painting and Popular History in Zaire. Berkeley: University of California Press.

Fabian, Johannes. 1998. Moments of Freedom: Anthropology and Popular Culture. Charlottesville \& London: University Press of Virginia. 
Ferguson, James. 1999. Expectations of Modernity: Myths and Meanings of Urban Life on the Zambian Copperbelt. Berkeley: University of California Press.

Gandoulou, Justin-Daniel. 1989. Au Coeur de la Sape: Moeurs et Aventures des Congolais à Paris. Paris: L'Harmattan.

Gondola, Ch. Didier. 1999. "Dream and Drama: The Search for Elegance among Congolese Youth." African Studies Review 42 (1): 23-48.

Gondola, Ch. Didier. 2016. Tropical Cowboys: Westerns, Violence, and Masculinity in Kinshasa. Bloomington \& Indianapolis: Indiana University Press.

Green-Simms, Lindsey. 2012. Hustlers, Home-wreckers and Homoeroticism: Nollywood's Beautiful Faces. Journal of African Cinemas, 4 (1): 59-79.

Green-Simms, Lindsay and Unoma Azuah. 2012. The Video Closet: Nollywood's GayThemed Movies. Transition, 107: 32-49.

Gunkel, Henriette. 2013. "Some Reflections on Postcolonial Homophobia, Local Interventions, and LGBTI Solidarity Online: the Politics of Global Petitions." African Studies Review 56 (2): 67-81.

Guyer, Jane. 1996. "Traditions of Invention in Equatorial Africa." African Studies Review 39: 1-28.

Hall, Stuart, 1981. 'Notes on Deconstructing 'the Popular'”. In People's History and Socialist Theory, edited by Raphael Samuel, 227-240. London: Routledge and Kegan Paul.

Hendriks, Thomas. 2016. "SIM Cards of Desire: Sexual Versatility and the Male Homoerotic Economy in Urban Congo.” American Ethnologist 43 (2): 230-242.

Hendriks, Thomas. 2017. “"Erotiques Cannibales”: A Queer Ontological Take on Desire from Urban Congo." Forthcoming in Sexualities

Herzfeld, Michael. 1997. Cultural Intimacy: Social Poetics in the Nation-State. New York: Routledge.

Hobsbawm, Eric and T.O. Ranger. 1983. The Invention of Tradition. Cambridge: Cambridge University Press.

Hunt, Nancy R. 2016. A Nervous State: Violence, Remedies, and Reverie in Colonial Congo. Durham: Duke University Press.

Jewsiewicki, Bogumil. 2003. Mami Wata: La Peinture Urbaine au Congo. Paris: Gallimard. Martin, P.M. 1995. Leisure and Society in Colonial Brazzaville. Cambridge: Cambridge University Press.

Mwangi, Evan. 2014. Queer Agency in Kenya's Digital Media. African Studies Review, 57 (2): 93-113.

Newell, Sasha. 2012. The Modernity Bluff: Crime, Consumption and Citizenship in Côte d'Ivoire. Chicago: Chicago University Press.

Newton, Esther. 1972. Mother Camp: Female Impersonators in America. Chicago: University 
of Chicago Press.

Ndjio, Basile. 2012. "Post-Colonial Histories of Sexuality: The Political Invention of a Libidinal African straight." Africa 82 (4): 609-631.

Pype, Katrien. 2011. "Taboos and Rebels - or, Transgression and Regulation in the Work and Lives of Kinshasa's Television Journalists.” Popular Communication 9 (2): 114-125.

Pype, Katrien. 2012. The Making of the Pentecostal Melodrama: Religion, Media and Gender in Kinshasa. New York and Oxford: Berghahn Books.

Pype, Katrien. 2015a. "Funerary Comedies in Contemporary Kinshasa: Social Difference, Urban Communities and the Emergence of a Cultural form." Africa 85(3): 457-477.

Reid, Graeme. 2003. “'It Is Just a Fashion!' Linking Homosexuality and 'Modernity' in South Africa." Etnofoor 16 (2): 7-25.

Tsika, Noah. 2014. “'Be Wary of Working Boys”: The Cultural Production of Queer Youth in Today's West Africa." In Queer Youth and Media Cultures, edited by Christopher Pullen, 239-250. London: Palgrave Macmillan.

Thoreson, Richard. 2014. "Troubling the Waters of a "Wave of Homophobia": Political Economies of Anti-Queer Animus in Sub-Saharan Africa." Sexualities 17 (1/2): 23-42.

Van Klinken, Adriaan. 2013. "Gay Rights, the Devil and the End Times: Public Religion and the Enchantment of the Homosexuality Debate in Zambia.” Religion 43 (4): 519-40.

White, Bob. 2008. Rumba Rules: The Politics of Dance Music in Mobutu's Zaire. Durham: Duke University Press. 